\title{
DAYA BUNUH LARUTAN TANAMAN DAUN SALAM (SYZYGIUM POLYANTHUM) TERHADAP KEMATIAN LARVA AEDES SP.
}

\author{
Herliya Fatimah, Isnawati, Tien Zubaidah \\ Prodi Sanitasi Lingkungan Poltekkes Kemenkes Banjarmasin \\ *Email korespondensi: herliyafatimah@gmail.com
}

\begin{abstract}
Dengue Hemorrhagic Fever (DHF) is increasing every day so it is necessary to control efforts, namely by killing larvae using bay leaf plants (Syzygium polyanthum). The purpose of this study was to determine the effectiveness of the larvicidal solution of bay leaf in controlling larvae of Aedes sp. This research uses the true experiment method with Post Test Only Group Design. The concentration variations used were $0 \%, 15 \%, 20 \%, 25 \%$, $30 \%$ and $35 \%$ in $100 \mathrm{~mL}$ of water with 4 repetitions. The population and samples used were Aedes aegypti and Aedes albopictus instar III larvae, each containing 600 larvae containing 25 larvae in each container. The results showed that the LC50 of bay leaf solution within 24 hours had the largest number of Aedes aegypti and Aedes albopictus larvae mortality at a concentration of $35 \%$ with $100 \%$ mortality. The results of the Anova Two Way test obtained a sig value. $0.000<a(0.05)$, meaning that there is an influence on the yield of dead larvae based on variations in concentration. It was concluded that each concentration of bay leaf solution could kill a different percentage of larvae. Suggestions for further researchers to determine the concentration variation of bay leaf larvicide solution which is more effective in killing Aedes sp.
\end{abstract}

Keywords: Larvae of Aedes aegypti, Aedes albopictus, Bay Leaf

\section{PENDAHULUAN}

Penyakit Demam Berdarah Dengue (DBD) ditularkan melalui gigitan nyamuk yang disebabkan oleh salah satu dari 4 virus dengue berbeda terutama Aedes aegyptiatau Aedes albopictus. Nyamuk ini dapat ditemukan di daerah tropis dan subtropis diantaranya bagian utara AustraIia hingga di kepulauan Indonesia (Berliano, Sudiawati NLPE, Ahmad ZS, 2019). Berdasarkan data World Health Organization (WHO) pada tahun 1968 hingga 2009 mencatat bahwa kasus DBD tertingi di Asia Tenggara adalah Indonesia (Achmadi, 2010 dalam Hidayat F, Noraida, 2019). Penyakit tersebut pertama kali ditemukan di kota Surabaya dimana sebanyak 58 orang terinfeksi dan 24 orang meninggal (Case Fatality Rate/CFR $41,3 \%$ ) (Sallata MHE, Ibrahim E, Selomo $M, 2013)$.

Di provinsi Kalimantan Selatan jumlah penderita DBD yang dilaporkan sebanyak 2.001 kasus dengan kematian 15 orang (Incidence Rate/Angka Kesakitan $=47,84$ per 100.000 penduduk dan CFR $=0,75 \%$ ). Di Kalimantan Selatan terdapat 13 kabupaten/kota dengan jumlah yang terjangkit sebesar $12(92,31$ \%) Kabupaten/Kota (Kemenkes RI, 2017).

Terdapat berbagai upaya pengendalian vektor untuk menekan angka kasus yang terjadi namun masih belum berhasil menurunkan angka kesakitan sehingga penyakit DBD cenderung meningkat dan penyebarannya yang semakin meluas. Cara pengendalian vektor tersebut yang dapat dilakukan yaitu secara nabati/alamiah yaitu menggunakan insektisida alami seperti daun salam (Syzygium polyanthum). Daun salam dipilih sebagai alternative larvasida karena tanaman ini telah banyak dikenal dikalangan masyarakat selain itu daun salam memilki kandungan senyawa yang dapat membunuh insekta.

Daun salam termasuk kedalam family Myrtaceace. Kandungan senyawa kimia yang terkandung di dalam daun salam yaitu, alkaloid, saponin, quinon, fenolik, triterpenoid, steroid dan flavonoid (Hasanah, 2015) minyak atsiri, saponin $(0.67 \pm 0.01 \%)$ dan tannin $(0.03 \pm 0.00 \%)$ (Sudirman, 2014). Kandungan flavonoid 
tertinggi adalah pada daun tua (ekstrak $2.05 \pm 0.58 \mathrm{mg}$ QE/ g), kemudian pada daun muda ( $1.81 \pm 0.76 \mathrm{mg} \mathrm{QE} / \mathrm{g}$ ekstrak) (Anggraini DA, Manzil LD. 2019).

Senyawa tersebut telah diteliti memiliki daya toksik dan sebagai larvasida pada berbagai macam insekta salah satunya ialah nyamuk Aedes aegypti dan Aedes albopictus.

Penelitian ini bertujuan untuk mengetahui efektivitas daun salam (Syzygium polyanthum) dalam membunuh larva nyamuk Aedes aegypti dan Aedes albopictus.

\section{BAHAN DAN METODE}

Penelitian ini dilaksanakan pada bulan April 2021 bertempat di Politeknik Kesehatan Banjarmasin Laboratorium Entomologi Jurusan Kesehatan Lingkungan yang beralamat di Jalan Haji Mistar Cokrokusumo No.1 A Banjarbaru dan di rumah peneliti di komplek Beringin, Kota Banjarbaru, Kalimantan Selatan. Variabel bebas pada penelitian ini adalah variasi konsentrasi larutan daun salam dengan konsentrasi $0 \%$ (kontrol), 15\%, $20 \%$, 25\%, 30\% dan 35\%. Variabel terikat pada penelitian ini adalah jumlah kematian larva Aedes aegypti dan Aedes albopictus. Variabel dikendalian pada penelitian ini adalah suhu air dan $\mathrm{pH}$ air. Jenis penelitian ini adalah eksperimen murni. Rancangan penelitian ini menggunakan post-test only control group design.

Penelitian ini menggunakan bahan daun salam (Syzygium polyanthum), larva Aedes aegypti dan Aedes albopictus, Aquadest. Sedangkan untuk ala-alat yang digunakan yaitu pipet tetes, pipet ukur 10 $\mathrm{ml}$, bola hisap, juicer, $\mathrm{pH}$ meter, thermometer, kontainer, kertas label, saringan dan mikroskop.

\section{Tahapan proses penelitian}

Siapkan bahan daun salam (Syzygium polyanthum) dicuci dengan air mengalir sampai bersih. Selanjutnya daun salam dimasukkan ke dalam juicer untuk dihaluskan. Kemudian air murni larutan daun salam dengan variasi konsentrasi $0 \%$ (kontrol), 15\%, 20\%, 25\%, 30\% dan $35 \%$ dimasukkan ke dalam masingmasing box container yang berisi air sebanyak $100 \mathrm{~mL}$. Aduk masing-masing box container yang berisi larvasida nabati daun salam supaya tercampur. Masukkan larva instar III masing-masing 25 larva Aedes aegypti ke dalam box container yang berisi larvasida nabati. Lihat dan catat jumlah kematian larva setelah 24 jam. Masukkan ke dalam tabel uji efektivitas dan ulangi hingga 4 kali pengulangan.

\section{HASIL DAN PEMBAHASAN}

Tabel 1

Data Hasil Uji Toksisitas Efektivitas Larutan Daun Salam (Syzygium polyanthum) Dalam Pengendalian Larva Aedes aegypti

\begin{tabular}{|c|c|c|c|c|c|c|}
\hline \multirow{2}{*}{$\begin{array}{l}\text { Jenis } \\
\text { Larva }\end{array}$} & \multirow[t]{2}{*}{ Konsentrasi } & \multicolumn{4}{|c|}{ Pengulangan } & \multirow[t]{2}{*}{ Rata-rata } \\
\hline & & R1 & $\mathbf{R 2}$ & R3 & R4 & \\
\hline \multirow{6}{*}{$\begin{array}{c}\text { Aedes } \\
\text { aegypti }\end{array}$} & $0 \%$ & 0 & 0 & 0 & 0 & 0 \\
\hline & $15 \%$ & 4 & 6 & 9 & 10 & 29 \\
\hline & $20 \%$ & 11 & 14 & 12 & 13 & 50 \\
\hline & $25 \%$ & 17 & 13 & 15 & 14 & 59 \\
\hline & $30 \%$ & 19 & 20 & 19 & 24 & 82 \\
\hline & $35 \%$ & 25 & 25 & 25 & 25 & 100 \\
\hline
\end{tabular}

Pada hasil uji toksisitas menunjukkan rata-rata kematian larva Aedes aegypti tertinggi pada uji toksisitas yaitu pada konsentrasi $35 \%$ sebanyak $100 \%$ dengan pengamatan 24 jam. Sedangkan rata-rata kematian larva Aedes aegypti terendah yaitu pada konsentrasi $15 \%$ sebanyak 29 ekor atau $29 \%$ dengan pengamatan 24 jam. 
Tabel 2

Data Hasil Uji Toksisitas Efektivitas Larutan Daun Salam (Syzygium polyanthum) Dalam Pengendalian Larva Aedes albopictus

\begin{tabular}{|c|c|c|c|c|c|c|}
\hline \multirow{2}{*}{$\begin{array}{l}\text { Jenis } \\
\text { Larva }\end{array}$} & \multirow[t]{2}{*}{ Konsentrasi } & \multicolumn{4}{|c|}{ Pengulangan } & \multirow[t]{2}{*}{ Rata-rata } \\
\hline & & R1 & R2 & R3 & R4 & \\
\hline \multirow{6}{*}{$\begin{array}{c}\text { Aedes } \\
\text { albopictus }\end{array}$} & $0 \%$ & 0 & 0 & 0 & 0 & 0 \\
\hline & $15 \%$ & 9 & 5 & 5 & 8 & 27 \\
\hline & $20 \%$ & 10 & 11 & 13 & 13 & 47 \\
\hline & $25 \%$ & 15 & 17 & 18 & 19 & 69 \\
\hline & $30 \%$ & 20 & 22 & 19 & 23 & 84 \\
\hline & $35 \%$ & 25 & 25 & 25 & 25 & 100 \\
\hline
\end{tabular}

Pada hasil uji toksisitas menunjukkan rata-rata kematian larva Aedes albopictus tertinggi yaitu pada konsentrasi $35 \%$ sebanyak $100 \%$ dengan pengamatan 24 jam. Sedangkan rata-rata kematian larva Aedes albopictus terendah yaitu pada konsentrasi $15 \%$ sebanyak 27 ekor atau $27 \%$ dengan pengamatan 24 jam.

Tabel 3

Hasil Pengukuran Suhu Uji Toksisitas

Variasi Konsentrasi Larutan Daun Salam (Syzygium polyanthum) dalam Pengendalian Larva Aedes aegypti

\begin{tabular}{cccccc}
\hline Jenis Larva & Konsentrasi & \multicolumn{4}{c}{ Pengulangan } \\
\cline { 2 - 5 } & & R1 & R2 & R3 & R4 \\
\hline \multirow{3}{*}{ Aedes aegypti } & $0 \%$ & 27,8 & 27,8 & 27,9 & 27,9 \\
\cline { 2 - 5 } & $15 \%$ & 27,9 & 27,9 & 27,9 & 27,9 \\
\cline { 2 - 5 } & $20 \%$ & 27,9 & 27,9 & 28,0 & 28,0 \\
\cline { 2 - 5 } & $25 \%$ & 28,0 & 28,0 & 28,0 & 28,0 \\
\cline { 2 - 5 } & $30 \%$ & 28,0 & 28,0 & 28,0 & 28,0 \\
\hline & $35 \%$ & 28,0 & 28,0 & 28,0 & 28,1 \\
\hline
\end{tabular}

Pada hasil pengukuran suhu uji toksisitas menunjukkan kematian larva Aedes aegypti tertinggi yaitu pada konsentrasi $25 \%, 30 \%$ dan $35 \%$ yaitu $28,0-28,1^{\circ} \mathrm{C}$ dengan pengamatan 24 jam.
Sedangkan kematian larva Aedes aegypti terendah yaitu pada konsentrasi $0 \%$ (kontrol) yaitu $27,8^{\circ} \mathrm{C}$ dengan pengamatan 24 jam.

Tabel 4

Hasil Pengukuran Suhu Uji Toksisitas Variasi Konsentrasi Larutan Daun Salam (Syzygium polyanthum) dalam Pengendalian Larva Aedes albopictus

\begin{tabular}{cccccc}
\hline Jenis Larva & Konsentrasi & \multicolumn{4}{c}{ Pengulangan } \\
\cline { 2 - 5 } & & $\mathbf{R 1}$ & $\mathbf{R 2}$ & $\mathbf{R 3}$ & $\mathbf{R 4}$ \\
\hline \multirow{3}{*}{ Aedes albopictus } & $0 \%$ & 27,9 & 27,9 & 27,9 & 28,0 \\
\cline { 2 - 5 } & $15 \%$ & 28,0 & 28,0 & 28,0 & 28,0 \\
\cline { 2 - 5 } & $20 \%$ & 28,0 & 28,0 & 28,0 & 28,0 \\
\cline { 2 - 5 } & $25 \%$ & 28,0 & 28,0 & 28,0 & 28,1 \\
\cline { 2 - 5 } & $30 \%$ & 28,0 & 28,0 & 28,1 & 28,1 \\
\hline & $35 \%$ & 28,0 & 28,0 & 28,1 & 28,2 \\
\hline
\end{tabular}

Pada hasil pengukuran suhu uji toksisitas menunjukkan kematian larva Aedes albopictus tertinggi pada uji toksisitas yaitu pada konsentrasi $15 \%$, $20 \%, 25 \%$, $30 \%$, dan $35 \%$ yaitu $28,0-$ $28,2^{\circ} \mathrm{C}$ dengan pengamatan 24 jam. Sedangkan kematian larva Aedes aegypti terendah yaitu pada konsentrasi $0 \%$ (kontrol) yaitu $27,9^{\circ} \mathrm{C}$ dengan pengamatan 24 jam. 


\section{Tabel 5}

Hasil Pengukuran pH Uji Toksisitas

Variasi Konsentrasi Larutan Daun Salam (Syzygium polyanthum) dalam Pengendalian Larva Aedes aegypti

\begin{tabular}{cccccc}
\hline Jenis Larva & \multirow{2}{*}{ Konsentrasi } & \multicolumn{4}{c}{ Pengulangan } \\
\cline { 2 - 5 } & & R1 & R2 & R3 & R4 \\
\hline \multirow{3}{*}{ Aedes aegypti } & $0 \%$ & 7,2 & 7,2 & 7,2 & 7,2 \\
\cline { 2 - 5 } & $15 \%$ & 6,8 & 6,8 & 6,8 & 6,8 \\
\cline { 2 - 5 } & $20 \%$ & 6,8 & 6,8 & 6,8 & 6,6 \\
\cline { 2 - 6 } & $25 \%$ & 6,6 & 6,6 & 6,5 & 6,5 \\
\cline { 2 - 6 } & $30 \%$ & 6,5 & 6,5 & 6,4 & 6,3 \\
\cline { 2 - 6 } & $35 \%$ & 6,2 & 6,2 & 6,1 & 6,1 \\
\hline
\end{tabular}

Pada hasil uji toksisitas menunjukkan pH pada kematian larva Aedes aegypti bersifat asam pada uji toksisitas dengan konsentrasi $30 \%$ dan $35 \%$ yaitu $6,1-6,4$ dengan pengamatan 24 jam. Sedangkan kematian larva Aedes aegypti dengan $\mathrm{pH}$ normal pada konsentrasi $0 \%$ (kontrol), $15 \%, 20 \%$, 25\% dan $30 \%$ yaitu $6,5-7,2$ dengan pengamatan 24 jam.

Tabel 6

Hasil Pengukuran pH Uji Toksisitas Variasi Konsentrasi Larutan Daun Salam (Syzygium polyanthum) dalam Pengendalian Larva Aedes albopictus

\begin{tabular}{cccccc}
\hline Jenis Larva & Konsentrasi & \multicolumn{4}{c}{ Pengulangan } \\
\cline { 2 - 5 } & & R1 & R2 & R3 & R4 \\
\hline \multirow{3}{*}{ Aedes albopictus } & $0 \%$ & 7,2 & 7,2 & 7,2 & 7,2 \\
\cline { 2 - 6 } & $15 \%$ & 6,8 & 6,8 & 6,8 & 6,7 \\
\cline { 2 - 5 } & $20 \%$ & 6,7 & 6,7 & 6,6 & 6,6 \\
\cline { 2 - 6 } & $25 \%$ & 6,5 & 6,4 & 6,3 & 6,3 \\
\cline { 2 - 6 } & $30 \%$ & 6,5 & 6,4 & 6,3 & 6,3 \\
\cline { 2 - 6 } & $35 \%$ & 6,2 & 6,1 & 6,1 & 6,1 \\
\hline
\end{tabular}

Pada hasil uji toksisitas menunjukkan pH pada kematian larva Aedes albopictus bersifat asam pada uji toksisitas dengan konsentrasi $25 \%$, $30 \%$ dan $35 \%$ yaitu 6,1-6,4 dengan pengamatan 24 jam. Sedangkan kematian larva Aedes albopictus dengan $\mathrm{pH}$ normal pada konsentrasi $0 \%$ (kontrol), 15\%, 20\% dan $25 \%$ yaitu $6,5-7,2$ dengan pengamatan 24 jam.

Hasil LC 50 larvasida larutan daun salam pada larva Aedes aegypti adalah $27,4 \%$ dengan batas atas $30.2 \%$ dan batas bawah $15,5 \%$ dan hasil dari LC $99_{9}$ larvasida larutan daun salam adalah $41.7 \%$. Sedangkan hasil $\mathrm{LC}_{50}$ larvasida larutan daun salam pada larva Aedes albopictus adalah $26,1 \%$ dengan batas atas $28,6 \%$ dan batas bawah $15,2 \%$ dan hasil dari $\mathrm{LC}_{99}$ larvasida larutan daun salam adalah 37,3\%. Hasil Uji data menggunakan Anova Two Way dengan nilai sig. $0,000<a(0,05)$, yang artinya ada pengaruh antara hasil larva mati berdasarkan variasi konsentrasi. Berdasarkan hasil Post Hoc semakin tinggi konsentrasi larutan yang diberikan maka semakin tinggi jumlah kematian pada larva.

Jumlah angka kematian larva tertinggi dapat dilihat pada variasi konsentrasi ke 35\%. Hal tersebut menunjukkan bahwa uji toksisitas larvasida menggunakan daun salam (Syzygium polyanthum) mampu mematikan larva Aedes aegyptidan Aedes albopictus dengan tingkat kematian mulai dari konsentrasi larutan $15 \%$ sampai dengan 35\%.

Kematian larva Aedes aegypti dan Aedes albopictus disebabkan karena zat aktif yang terdapat pada daun salam. Zat aktif tersebut antara lain flavonoid, alkaloid, minyak atsiri (tannin dan 
saponin). Kandungan zat aktif tersebut merupakan zat toksik yang dapat membunuh larva sehingga larva yang diuji akan mati.

Berdasarkan penelitian Cania, E (2013) flavonoid bekerja dengan masuk kedalam tubuh larva melalui sistem pernapasan yang akan menjadikan kelayuan pada syaraf, kerusakan sistem pernapasan dan mengakibatkan larva tidak bisa bernapas dan akhirnya mati. Flavonoid juga disebut sebagai racun pernapasan. Senyawa flavonoid bekeja di dalam tubuh larva melalui shipon. Shipon akan rusak dan akan mengalami kelayuan pada saraf sehingga sistem pernapasan pada larva akan terganggu secara perlahan dan akan mati.

Senyawa bioaktif seperti saponin dan tanin bertindak sebagai racun perut. Eugenol bersifat neurotoksik yang mempengaruhi susunan saraf yang khas dipunyai oleh serangga dan tidak terdapat pada hewan berdarah panas. Komponen dari suatu bahan tumbuhan dapat dipisahkan dengan cara ekstraksi. Granul lebih tahan terhadap pengaruh udara sehingga senyawa yang terkandung dalam granul tidak mudah menguap. Bentuk granul lebih aplikatif dan dapat menuju ke dasar air sebagai tempat hidup larva. Daun salam yang mudah didapatkan, diduga dapat dimanfaatkan sebagai insektisida nabati karena memiliki kelebihan kandungan minyak atsiri berupa eugenol yang tidak dimiliki oleh semua jenis tumbuhan.

Alkaloid dapat mendegradasi membran sel dan merusak sel yang dapat mengganggu sistem kerja syaraf larva. Alkaloid juga dapat menyebabkan terjadinya perubahan tubuh pada larva yang menjadi lebih transparan dan gerakan larva yang melambat. Cania, E (2013). Larva sedikit demi sedikit akan mengalami perubahan tingkah laku yang dimana sebelumnya bergerak dengan sangat aktif akan menjadi lamban dikarenakan setelah diberi konsentrasi larutan daun salam. Jika larva sudah tidak bergerak saat disentuh atau berada didasar air dan tidak muncul ke permukaan air maka larva tersebut bisa dikatakan mati. Larva yang mati terlihat berwarna putih pucat.
Berdasarkan penelitian Listyorini.PI (2012) menunjukkan bahwa senyawa metabolit sekunder ekstrak kayu jati (Tectona grandis L.F) sebagai larvasida nyamuk Aedes aegypti masih aman bagi mencit. Selain itu, tidak membunuh dan tidak menimbulkan gejala toksik pada dosis yang sesuai. Jadi dapat dikatakan daun salam yang biasanya digunakan sebagai bumbu dapur tidak menimbulkan efek toksik bagi manusia berdasarkan senyawa metabolit sekunder yang terkandung.

Variabel dikendalikan pada penelitian ini yaitu suhu air san $\mathrm{pH}$ air, sehingga tidak berpengaruh pada larva yang diuji. Suhu tidak berpengaruh pada kematian larva karena termasuk dalam kriteria pertumbuhan yang optimal untuk perkembangan larva Aedes aegypti dan Aedes albopictus yaitu pada suhu 25$30^{\circ} \mathrm{C}$. sedangkan $\mathrm{pH}$ tidak berpengaruh karena perkembangan larva Aedes aegypti dan Aedes albopictus yaitu pada pH 3-12.

\section{KESIMPULAN}

Berdasarkan hasil penelitian yang dilakukan yaitu efektivitas larutan daun salam (Syzygium polyanthum) dalam pengendalian larva Aedes sp. maka dapat diambil kesimpulan bahwa pengaruh variasi konsentrasi larutan daun salam dalam pengendalian larva Aedes aegypti dan Aedes albopictus pada uji Anova Two Way dengan hasil nilai sig. 0,000 < a $(0,05)$ yang artinya ada pengaruh antara hasil larva mati berdasarkan variasi konsentrasi.

\section{SARAN}

Bagi peneliti selanjutnya perlu dilakukan penelitian lebih lanjut seperti menemukan konsentrasi larvasida larutan daun salam (Syzygium polyanthum) yang lebih efektif dalam pengendalian larva Aedes $s p$. dengan skala yang besar dan lebih aplikatif, sehingga penggunaannya lebih mudah dan praktis.

\section{DAFTAR PUSTAKA}

Berliano, Sudiawati NLPE, Ahmad ZS. (2019). Pengaruh Pemberian Penyuluhan Terhadap Kemampuan Keluarga Dalam Mendeteksi Demam 
Berdarah Dengue (DBD) Pada Anak. 2019;4.

Hidayat F, Noraida. (2019). Pengetahuan dan Praktik Pemberantasan Sarang Nyamuk Terhadap Tempat Perindukan Vektor DBD. J Kesehat Lingkung J dan Apl Tek Kesehat Lingkung 2019;16(2):769.

Sallata MHE, Ibrahim $E$, Selomo $M$. (2013). Hubungan Karakteristik Lingkungan Fisik dan Kimia dengan Keberadaan Larva Aedes aegypti di Wilayah Endemis DBD Kota Makassar. Univ Hasanuddin [Internet] 2013;1-10.

Kemenkes RI. (2018). Profil Kemenkes RI [Internet]. Jakarta

Hasanah N. (2015). Aktivitas Antioksidan Ekstrak Etanol Daun Salam. J Pena Med [Internet] 2015;5(1):55-9.
Sudirman TA. (2014). Uji Efektivitas Ekstrak Daun Salam (Eugenia polyantha) Terhadap Pertumbuhan Staphylococcus Aureus Secara In Vitro Skripsi

Anggraini DA, Manzil LD. (2019). Pengaruh Penanmbahan Larutan Daun Salam (Syzygium polyanthum) Terhadap Kematian Larva Aedes aegypti. junal Sains 2019;9(17):116.

Cania E, Setyaningrum E. (2013). Uji Efektivitas Larvasida Ekstrak Daun Legundi (Vitex trifolia) Terhadap Larva Aedes aegypti. J Med Lampung Univ 2013;2(4):52-60.

Listyorini PI. (2012). Uji Keamanan Ekstrak Kayu Jati (Tectona grandis I.f) Sebagai Bio-Larvasida Aedes aegyptiTerhadap Mencit 